\title{
Effect of Sweetpotato Leaf (Ipomoea Batatas) Extract On Some Haematological Parameters Using Rabbits
}

\author{
* Osime E.O., * Ediale G.E., ${ }^{* *}$ Omoti C.E., And ${ }^{* *}$ Famodu A.A.
}

\begin{abstract}
SUMMARY
The use of plants and herbs as food supplements and medicinal additives is fast gaining grounds and recognition in the world especially in Africa. Sweet potato leaves (Ipomoea batatas) decoction is a folk remedy for asthma, bugbites, burns, catarrh, diarrhea, fever, nausea, stomach distress and tumours. Also this plant has haematinic effects and has been used in the treatment of anaemia and other related ailments. Sweet potato leaves were used to feed rabbits. Their blood samples were collected and analysed for PCV, WBC, platelet count and white cell differential count. There was a significant increase in PCV, WBC and platelet count $(\mathrm{P}<0.05)$ respectively. While the differential white cell count remained the same. Increase in haematological parameters after feeding with the sweet potato leave extract may be a direct effect on haemopoietic tissues.
\end{abstract}

\section{INTRODUCTION}

Sweet potato (Ipomoea batatas) is a creeping plant with perennial vines and adventitious roots, some of which produce swollen tubers. It is an ancient food from tropical America and the Pacific Island. It can be grown in well-drained loamy soil, which is rich in humus to provide a warm and moist environment to the root. It is mainly cultivated from the tubers, used as vegetables, eaten boiled, baked, fried and grounded into flour to make biscuit, bread and other pastries.

KEYWORDS: Sweet potato leaves (Ipomoea batatas)

${ }^{*}$ Departments of School of Medical Laboratory Sciences, **Department of Haematology University of Benin Teaching Hospital P.M.B. 1111, Benin City

All Correspondence to: Osime E.O. AILMLS, FIMLS, MSC School of Medical Laboratory Sciences University of Benin Teaching Hospital PMB 1111, Benin City, Nigeria
The leaves of sweet potato is used as potherb in Southeast Asia, they can also be used as forage and the leaf has rich protein content that helps to fill the nutritional gap. The leaf decoction of sweet potato is used in folk remedies for the tumour of the mouth and throat. It can also be used as an alternative for astringent, tonic, laxative, fungicide. ${ }^{1}$

Sweet potatoes merit a place in tropical gardens because it is easy to cultivate and yield edible tubers as well as leaves. The leaves are rich sources of protein, carbohydrates and fat. ${ }^{2}$

It has been shown that this plant has haematinic effects and has been used in the treatment of anaemia and other related ailments. The aim of this work is to investigate the effect of sweet potato leaf extract on some haemotological parameters in experimental animals.

\section{MATERIALS AND METHODS}

A total of eight (8) adult New Zealand white 
rabbits were used for the study. They were feed with grower's mash purchased from reputable sales depot in Benin City. They were assigned into two groups of four i.e. test and control. The extract was administered to the rabbit orally by withdrawing into a syringe and injected into the mouth of the test animals. $1 \mathrm{ml}$ of the extract was administered daily for the first 2 weeks then $3 \mathrm{mls}$ of the extract was administered daily for the next 2 weeks. Lastly $5 \mathrm{mls}$ of the extract was administered for the last 2 weeks. The control rabbit were given tap water instead of the sweet potato leaf extract.

Blood samples were collected at the end of every week and the following parameters assayed for PCV, white cell count total and differential and platelet count using standard method as described by Dacie and Lewis. ${ }^{3}$

\section{RESULTS}

A total of 8 New Zealand rabbits were divided in 2 groups (test and control group). The following haematological parameters were determined packed cell volume (PCV), white cell count (WBC), platelet count and differential leucocyte count. The results were subjected to statistical analysis using student t-test.

Table 1: Nutritional Importance and Composition

\begin{tabular}{lll}
\hline & Leaves & Root \\
\hline Protein $(\mathrm{g})$ & 3.20 & $1.00-9.00$ \\
\hline Carbohydrates $(\mathrm{g})$ & 8.00 & $25.60-28.50$ \\
\hline Fats $(\mathrm{g})$ & 0.70 & $0.20-0.30$ \\
\hline Iron $(\mathrm{mg})$ & 4.50 & $0.90-2.00$ \\
\hline Phosphorus $(\mathrm{mg})$ & 91.00 & $38.00-50.00$ \\
\hline Ascorbic acid (mg) & 17.00 & $21.00-27.00$
\end{tabular}

\section{Martins, 1984}

Table 2: $\quad$ Mean \pm Standard Deviation of haematological parameters following

Feeding with $1 \mathrm{ml}, 3 \mathrm{mls}$ and $5 \mathrm{mls}$ of potato leaves extract

\begin{tabular}{|c|c|c|c|c|c|}
\hline & PCV (\%) & WBC (u) & Platelet (u) & Neut (\%) & Lymph (\%) \\
\hline \multicolumn{6}{|c|}{ After $1 \mathrm{ml}$ potato leave extract } \\
\hline 1st wk & 35.0 & $4,587.5$ & 156,250 & 43.5 & 56.5 \\
\hline 2nd wk & 35.3 & $4,650.0$ & 200,250 & 45.0 & 44.0 \\
\hline \multicolumn{6}{|c|}{ After $3 \mathrm{mls}$ potato leave extract } \\
\hline 1st wk & 39.0 & $5,825.0$ & 239,000 & 43.3 & 56.8 \\
\hline 2nd wk & 40.5 & $5,987.0$ & 350,000 & 53.0 & 47.0 \\
\hline \multicolumn{6}{|c|}{ After $3 \mathrm{mls}$ potato leave extract } \\
\hline 1st wk & 41.8 & $6,600.0$ & 355,000 & 53.3 & 46.8 \\
\hline 2nd wk & 43.0 & $7,700.0$ & 350,000 & 51.5 & 48.5 \\
\hline
\end{tabular}




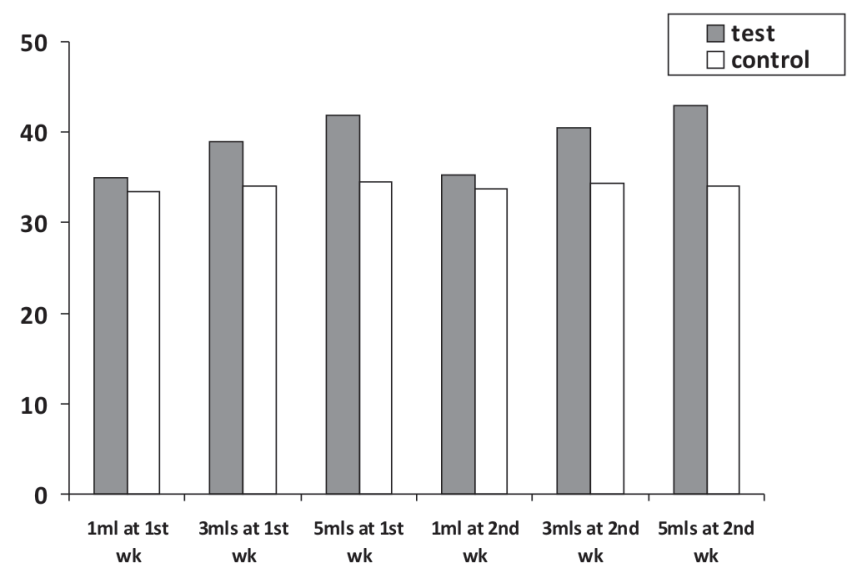

FIG 1: Packed Cell Volume (PCV) changes in control and test animals during feeding with different volumes of feeding with the leaf extract.

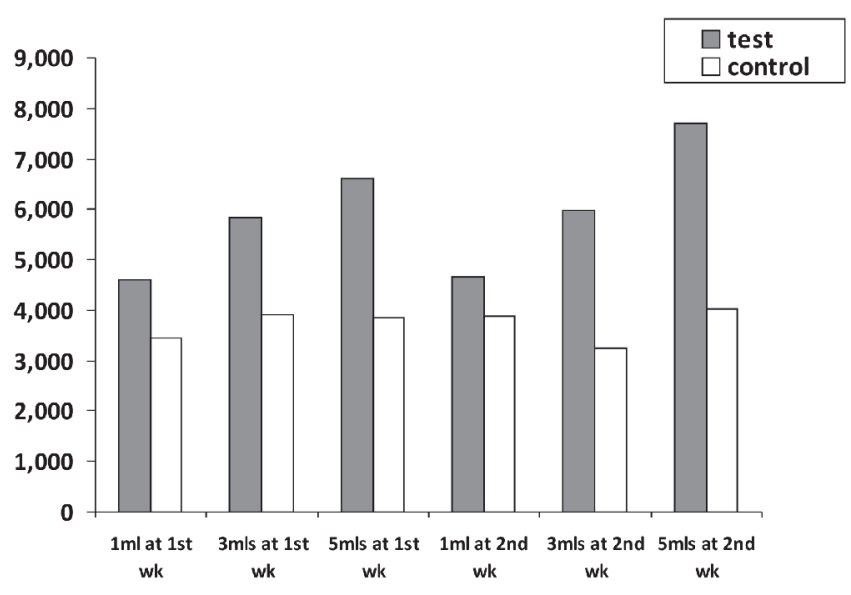

FIG 2: While Blood Cell (WBC) changes in control and test animals during feeding with different volumes of feeding with the leaf extract.

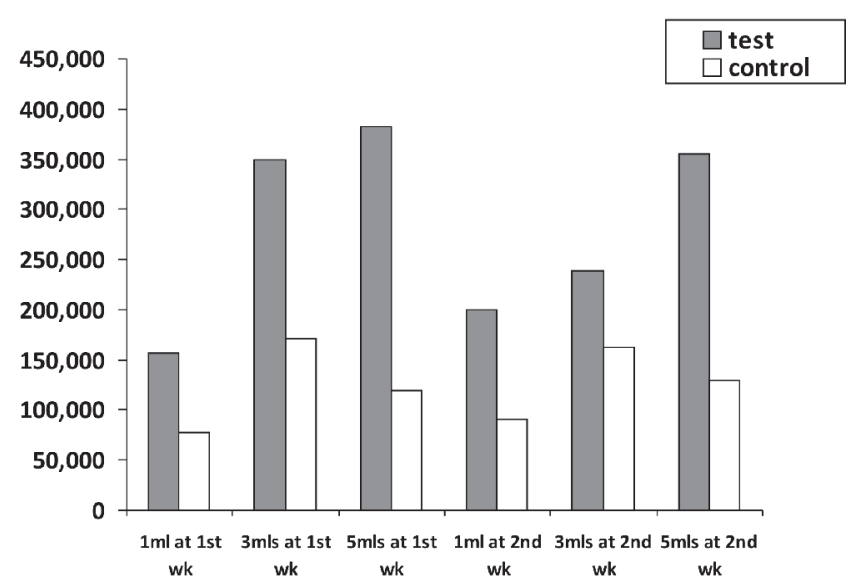

FIG 3: Platelet changes in control and test animals during feeding with different volumes of feeding with the leaf extract.

\section{DISCUSSION}

The haemopoietic activity of this plant has been investigated in this study and has been able to define to some extent, the role of the extract on haemopoises. In the week before the experimental feeding of the animals with the extract, all parameters of both control and test group showed no significant difference.

In the first week of experimental feeding with $1 \mathrm{ml}$ of the extract there was a slight increase on WBC $(\mathrm{P}<0.05)$, while other parameters show no significant changes. When the dose of extract was increased to $3 \mathrm{mls}$, the first week recorded a statistically significant increase in all the parameter $(\mathrm{P}<0.05)$ except in the differential while cells which was also the case at the second week proving right the work of Hartwell (1971) indicating that sweet potato leave can stimulate haemopoietic organ for the red cell production. This can also be compared with similar work done on Ugu leaf extract3,4 which found out that people benefit tremendously from Ugu extract through its activities by stimulating the bone marrow to produce blood cells and maintenance of body resistance to infection. At $5 \mathrm{mls}$ dosage, the first week produces almost the same effects as in the $3 \mathrm{mls}$ dosage and this effect continued in the second week.

This study shows that there was an enhanced haemopoietic activity that was observed with $5 \mathrm{mls}$ of extract, this was confirmed when $3 \mathrm{mls}$ and $5 \mathrm{mls}$ were compared. The increase in haemotological parameters that was recorded in this study after feeding the animals with sweet potato extract is in agreement with Hartwell (1971) although the precise mechanism of action was not documented but it could be a direct stimulation of haemopoietic organs such as the liver and bone marrow. Also in this study, the effect of sweet potato leaf extract was also observed in one of the rabbit that had a tumour which later disappeared and which 
was in agreement with (Hartwell, 1971) as a folk remedy for tumour of the mouth and throat.

\section{CONCLUSION}

In conclusion, increase in haematological parameters such as PCV, WBC, platelet count may be a direct effect of the extract on haemopoiesis. Adding the leaf as part of daily diet may reduce anaemia in human.

\section{References}

1. Hartwell, J. L. (1971), Plants used Against Cancer. A survey. Lloyd 3034

2. Martins, W. F. (1984), A handbook of tropical food crops (Florida) pp 126129
3. Dacie, J. V. and Lewis, S. M. (1991), Practical Haematology 7th Ed. Churchill Livingstone (London) pp $659-661$

4. Kafaru, E. (1999), The medicinal values of Fluted Pumpkin leaves. The Guardian, June 10; pp 30

5. Ajayi, O. I., Ajayi, T. C., Omokaro, E. V. and Halim, N. K. D. (2000), Erythropoietic value of Pumpkin Lea Extract (Telfaira occidentalis) In Rabbits A Preliminary Study. Nigerian Journal of Physiological Sciences, 16:1- 3 . 